\title{
BENTHIC FORAMINIFERA ASSOCIATED WITH THE ZOOXANTHELLATE CORAL CLADOCORA IN THE PLEISTOCENE OF THE KOS ISLAND (AEGEAN SEA, GREECE): SEA LEVEL CHANGES AND PALAEOENVIRONMENTAL CONDITIONS
}

\author{
Drinia, H. ${ }^{1}$, Koskeridou, E. ${ }^{1}$, Antonarakou, A. ${ }^{1}$, and Tzortzaki, E. ${ }^{1}$ \\ ${ }^{1}$ University of Athens, Faculty of Geology and Geoenvironment, Department of Hist. Geology - Palaeontology, \\ 15784 Athens, Greece, cntrinia@geol.uoa.gr
}

\begin{abstract}
A Pleistocene section, cropping out in the northern Kos Island has been selected for study. The main lithology (clayey sands, sandy marls) of the section is interrupted by a prominent Cladocora bank which allows a proper extraction of its faunal contents and identification at species level. The evaluation of benthic foraminiferal assemblages from this bank helps to determine the range of the environmental controls in sedimentation. The foraminiferal assemblage is related to a relatively high supply of organic material and rather strong current intensities in water depth of the coral growth. We suggest that the fossil reef of Cladocora grew in coastal waters characterised by a marked seasonality, with periodical inputs of terrigenous sediments, moderate turbidity and higher temperature than today. Such results, although preliminary, suggest that Cladocora together with benthic foraminifera could be reference species for future work on changing Mediterranean climate and sea level.
\end{abstract}

Key words: benthic foraminifera, palaeoenvironment, Pleistocene, coral bank, SE Greece.

\section{Introduction}

The Mediterranean Sea is an interesting place to study global change because it is land-locked and acts like a miniature ocean, which reacts faster to environmental changes than the open ocean (Béthoux et al., 1990). Under this respect, the study of Mediterranean faunas can be used to model predictions on how this semi-enclosed basin responds to global climatic and environmental change.

One important tool for monitor these environmental and climatic changes is the distribution and abundance of benthic foraminifera in paralic and shallow marine environments. It is well documented that benthic foraminifera are very sensitive to variations in depth, salinity and substrate texture (Murray, 1991). Consequently, benthic foraminiferal assemblages preserved in the sedimentary record provide a useful palaeoecological indicator, because some taxa tolerate extreme conditions but react very quickly to environmental changes (e.g. Jorissen 1987, 1988; Murray 1991).

Cladocora coral is endemic and present throughout the whole Mediterranean (Zibrowius, 1980; Peirano et al., 1998). Large fossil Cladocora formations were found as old as Late Pliocene, when this coral formed true reefs both in the Eastern and Western Mediterranean Sea (Aguirre and Jiménez, 1998; Dornbos and Wilson, 1999). Large fossil banks of Cladocora are also known from the Early 


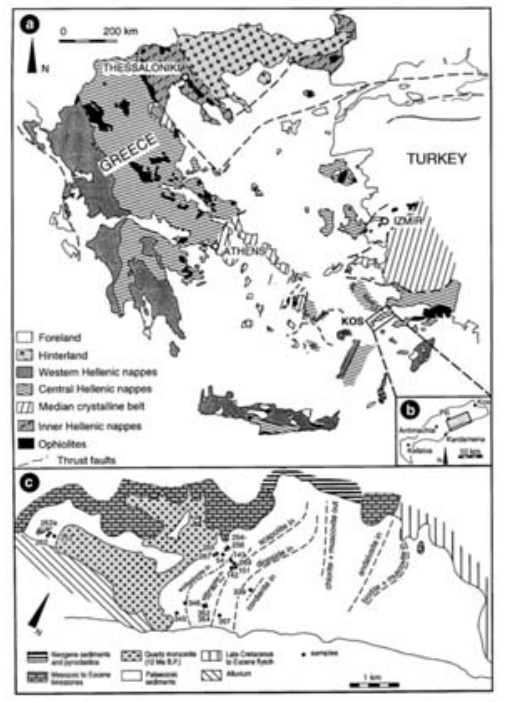

Fig. 1: (a) Geological sketch map of the Hellenic - Tauric orogenic belt in southeastern Europe and Turkey, modified after Jacobschagen (1986) and Kalt et al. (1998), showing the main tectonic units and the location of the Kos Island. (b), (c), location and geological features of the Dicheo Massif, including mineral isograds in the Palaeozoic sediments, resulting from contact metamorphism of the quartz monzonite (Altherr et al. 1976, Kalt et al. 1998).

Pleistocene (Bernasconi et al., 1997), from the Middle and Late Pleistocene and from the Holocene (for a review, see Peirano et al., 1998). The bathymetric distributions of these corals range from 5 to $40 \mathrm{~m}$ depth and they are well adapted to turbid coastal environments with high sedimentation rates (Zibrowius, 1974; Peirano et al., 2005).

The aim of the present study is to document the benthic foraminiferal faunal composition of a well exposed Cladocora caespitosa bank of Pleistocene age on the eastern Mediterranean island of Kos. The evaluation of benthic foraminiferal assemblages from this coral bank will help to characterize the range of the environmental controls in sedimentation.

\section{Geological setting}

The island of Kos off the Turkish coast in the Eastern Aegean Sea (Fig. 1) forms part of the HellenicTauric system, a complex mountain belt extending from southeastern Europe to Turkey. The Hellenic arc results from the collision of the Apulian microcontinent with the crystalline complexes of northeastern Greece during Mesozoic to Cenozoic times. It displays a pronounced southwest vergent nappe character. Apart from minor Palaeozoic units, the nappes consist of Mesozoic to Cenozoic sediments and magmatic rocks, including ophiolites. Some of these nappes have been subject to different degrees of metamorphism during collision (Jacobshagen 1986). Metamorphism and thrusting took place during several events between Jurassic and Miocene times (Altherr et al. 1994, Seidel et al. 1977, 1982).

The geological units on the island of Kos form part of the Central Hellenic nappes (Fig. 1, Jacobshagen 1986). The oldest units form the Dicheo Massif in the central part of the island towards the south coast (Fig. 1b and c). They consist of Permocarboniferous marls, impure limestones and sandstones, phyllites and rare mafic intercalations (Altherr et al. 1976, Gralla 1982) that have been subject to post-Permocarboniferous regional metamorphism at very low grades. At $12 \mathrm{Ma}$, this series was partly contact metamorphosed by the intrusion of a large quartz monzonite (Altherr et al. 1982, Henjes-Kunst et al. 1988). Subsequent to intrusion and exhumation Permocarboniferous metasediments and Miocene quartz monzonite were tectonically overridden by Cretaceous to Eocene lime- 
stones that crop out mainly north and west of the pluton (Fig. 1c). After tectonic emplacement of these limestones, the area west of the Dicheo Massif was covered by Pliocene and Pleistocene sediments and mostly Quaternary volcanics (Keller 1969; Dürr and Jacobshagen 1986). To the east, the Dicheo Massif is tectonically bordered by a flysch sequence of Late Cretaceous to Tertiary age (Dürr and Jacobshagen 1986).

The Neogene sedimentary cover of Kos consists of Lower Miocene molassic sediments on western Kos unconformably overlying the Mesozoic carbonates (Papanikolaou and Nomikou 1998), and north of the Dicheos window ranges from middle Miocene to Pleistocene shallow marine to terrestrial deposits (Böger et al. 1974, Altherr et al. 1976, Willmann 1983). It dips southward as a result of northdipping normal faults that separate the sediments from the pre- Neogene basement (Böger et al. 1974).

The island of Kos is dominantly non-volcanic but contains Miocene to Pleistocene volcanic centres. The Kamari caldera is of mid-Pleistocene age and contains the 1.0-0.55 million-year-old, postcaldera Zini lava dome. The widespread Kos Plateau Tuff (160,000 years ago), which blankets much of the western half of Kos, originated from a submarine source between Kos and Nisyros islands and resulted in the formation of a large caldera. The caldera dimensions are uncertain, but may extend as much as 20 kilometres from Kefalos Bay in southwestern Kos Island to Nisyros Island. Several solfatara fields are found on Kos Island, including Vromotopos at Kefalos Isthmus on the western side of the island and a group of thermal areas at the eastern side of Kos. Thermal activity consists of weak hydrogen sulfide emission, sulfur deposits, and two hot springs along the southeastern coast.

Bardintzeff et al. (1989) grouped the Kos volcanism into two eruptive episodes which have occurred during the Tertiary and Quaternary eras. A Miocene (10.4-7.5 Ma) subduction-related early episode which produced a welded ignimbrite formation exposed throughout the whole island, and a more recent $(\sim 2.7 \mathrm{Ma})$ episode which is related to the present subduction of the African plate beneath the Aegean micro-plate, associated with eruptive products which can be observed only in the central and western parts of Kos.

\section{Material and Methods}

\subsection{The coral-bearing unit}

The sediment samples used in this investigation were collected from the basal part of a section cropping out along Mastichari Bay, north Kos Island, located under the Kos ignimbrite which is dated to $145000 \pm 5000$ years BP and represents an important volcano-stratigraphic time-marker in the Eastern Mediterranean. Foraminiferal faunas were examined in one representative sample recovered from the studied succession (Fig. 2).

The relevant outcrop exposes a deepening - upwards succession with littoral sands at the base giving way to nearshore silts and sands with a very rich marine macrofauna assemblage including Cladocora caespitosa corals (sample K13 in Fig. 2). According to Peirano et al. (2004), the assemblage is typical of temperate-warm, shallow sea and of mixed carbonate-terrigenous, infralittoral environment.

\subsection{Micropalaeontological analysis}

In the laboratory, foraminifera were separated from the sediments by washing them through a 125 $\mu \mathrm{m}$ sieve. Identification of benthic foraminiferal species relies upon original descriptions and several key papers (Jorissen 1988, Albani and Serandrei Barbero 1990, Cimerman and Langer 1991, Sgarrella and Moncharmont Zei 1993, Fiorini and Vaiani 2001). 

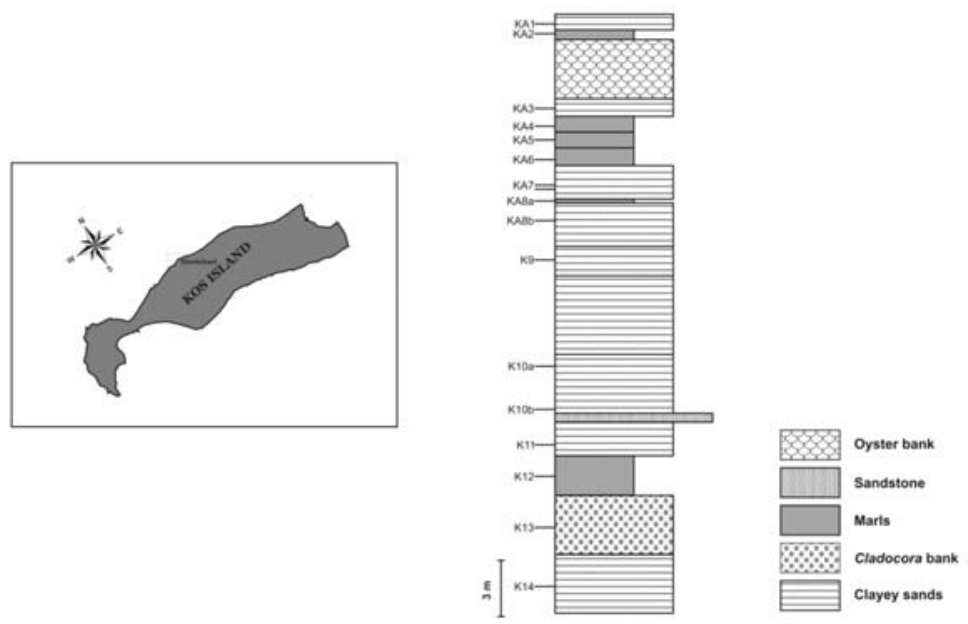

Fig. 2: Lithostratigraphical column of the studied section, showing the studied Cladocora bank.

Benthic foraminiferal assemblage diversity (Fisher alpha-diversity) was determined by plotting the total number of individuals against the total number of species in a Fisher alpha-a diversity basegraph. Species richness diversity was determined for the sample, categorized as very low (1-7 species), low (8-25), medium (26-50), or high (51-79).

Ecological interpretation of species and environmental significance of microfaunal associations are inferred from comparison with modern benthic communities (Jorissen 1987, Murray 1991, Van der Zwaan and Jorissen 1991, Barmawidjaja et al. 1992, Yassini and Jones 1995, Debenay et al. 2000, Donnici and Serandrei Barbero 2002) and similar microfaunal assemblages recorded within late Quaternary coastal successions of the Mediterranean.

Planktonic foraminifera are treated as a separate group; their proportional abundance (in $\%$ of the foraminiferal assemblages) was calculated.

\section{Results-Discussion}

A total of 287 specimens belonging to 20 species have been identified in the studied sample on which it was possible to perform a quantitative analysis. Only well-preserved tests (without breakages or abrasions) that did not show any sign of reworking and/or transportation were counted and, as a consequence, considered in the statistical analysis. However, most of the individuals do not show signs of re-deposition.

Benthic foraminifera are large- to medium-sized and usually well preserved; only a few specimens are fragmented. Furthermore, the presence of a relatively large amount (6\%) of highly-reworked planktonic foraminifera was noticed.

The low number of taxa (20) of benthic foraminifera in this "microenvironment' suggests 'drastic' ecological conditions for the benthic microfauna. Since planktonic remains are restricted to low percentage values we conclude that the deviation from the norm of palaeoenvironmental conditions is affecting the preservation of biogenic material and limiting the establishment of the benthic population. 
The foraminiferal assemblage is moderately diversified (Shannon index: 2.218 and Fisher-alpha index: 4.891), consisting of Ammonia beccarii group (27.87\%), Haynesina depressula (16.72\%), Cibicides lobatulus group (11.85\%) and Neoconorbina terquemi (14.63\%).

The high abundance values of $A$. beccarii are indicative of a shallow-marine environment with sandy bottom (Sgarrella and Moncharmont Zei 1993). Jorissen (1988) found that this species is very abundant in the Adriatic along a belt parallel to the Italian coast at a water depth of less than $20 \mathrm{~m}$. The highest abundance is found between 15 and $20 \mathrm{~m}$ water-depth in samples with intermediate percentages of organic matter in which at least some sand fraction is present. A strict interpretation based on the known modern distribution of $A$. beccarii would confine the species to upper shoreface environments (Hayward et al. 2004).

The high occurrence of $H$. depressula indicates increasing salinity together with $\mathrm{pH}>6.0$ and less stressful environmental conditions.

Cibicides locatulus group together with Neoconorbina terquemi represent species with strong positive correlation with sandy substrates and a negative one with organic matter. They are epiphytic species, preferring the presence of vegetation.

The moderate frequency values of Cancris oblongus indicate tolerance to mesotrophic - eutrophic conditions.

Cladocora caespitosa colonies occupy a wide ecological range, from hard to soft substrates and from low- to high-turbulence water (Zibrowius 1980; Schiller 1993a). The abundance of Cladocora fragments with the in situ colonies reinforces the indication by foraminiferal assemblage for preservation in moderate-energy shallow environment.

\section{Conclusions}

The micropalaeontological analysis allows us to describe the microenvironments, considering ecological conditions as well as preservation and/or sedimentary features.

The microfaunal assemblage is indicative of a marine environment characterised by moderate water energy. The absence of turbulent deposition and the presence of vegetation, as this is illustrated by the high frequency numbers of epiphytal species, usually set a depth limit of approximately 5-20 m although these plants may sporadically also reach down to $45 \mathrm{~m}$ deep (Langer 1993). The foraminiferal assemblage supports and extends these conclusions. Haynesina and Ammonia favour a water depth of 0-50 m (Murray 1991, 2006).

In conclusion, the foraminifera suggest an infralittoral environment with a water depth of between 20 and $50 \mathrm{~m}$. This interpretation is supported by the low abundance of planktonic foraminifera and medium diversity of benthic foraminifera. The diversity of the latter group increases with water depth, and a low-diversity benthic foraminifer fauna is generally typical for marginal marine environments (Sen Gupta 1999, Murray 1991, 2006).

The assemblage is indicative of an infralittoral environment with vegetation cover as suggested by the presence of epiphytic species. Species adapted to live in coarser substrates are also abundant. The presence of Haynesina depressula suggests relatively high concentrations of organic matter.

\section{Acknowledgments}

The authors wish to thank the two reviewers for their suggestions on the manuscript. 


\section{References}

Aguirre, J., Jiménez, A.P. 2008. Fossil analogues of present-day Cladocora caespitose coral banks: Sedimentary setting, dwelling community and taphonomy (Late Pliocene, W. Mediterranean), Coral Reefs 17, 203-213.

Albani, A., Serandrei Barbero, R. 1990. I foraminiferi della laguna e del Golfo di Venezia, Memorie di Scienze Geologiche (Padova) 42, 271-341.

Altherr, R., Keller, J., Kott, K. 1976. Der jungtertiäre Monzonit von Kos und sein Kontaktof (Agäis, Griechenland), Bulletin de la Société Géologique de France 7, 403-412.

Altherr, R., Kreuzer, H., Wendt, I., Lenz, H., Wagner, G.A., Keller, J., Harre, W., Höhndorf, A. 1982 . A late Oligocene/early Miocene high temperature belt in the Attic-Cycladic Crystalline Comples (SE Pelagonian, Greece, N. Jahrb. Geol. E23, 97-164.

Altherr, R., Kreuzer, H., Lenz, H., Wendt, I., Harre, W., Dürr, S. 1994. Further evidence for a late Cretaceous low-pressure/high temperature terrane in the Cyclades, Greece, Chimie der Erde 54, 319-328.

Bardintzeff, J.-M., Dalabakis, P., Traineau, H., Brousse, R. 1989. Recent explosive volcanic episodes on the Island of Kos (Greece): associated hydrothermal parageneses and geothermal area of Volcania, Terra Res. I, 15-78.

Barmawidjaja, D.M., Jorissen, F.J., Puskaric, S., van der Zwaan, G.J. 1992. Microhabitat selection by benthic foraminifera in the northern Adriatic Sea, J. Foram. Res. 22, 297-317.

Bernasconi, M.P., Corselli, C., Carobene, L. 1997. A bank of the scleractinian coral Cladocora caespitosa in the Pleistocene of the Crati valley (Calabria, southern Italy): growth versus environmental conditions, Boll. Soc. Paleontol. Ital. 36, 53-61.

Béthoux, J.P., Gentili, B., Raunet, J., Taillez, D. 1990. Warming trend in the Western Mediterranean Deep Water, Nature 347, 660-662.

Böger, H., Gersonde, R., Willman, R. 1974. Das Neogen im Osten der Insel Kos (Agäis, Dodekanes) Stratigraphie und Tektonik, Neues Jahrbuch Geologie und Palaeontologie Abh. 145, 129-152.

Cimerman, F., Langer, M.R. 1991. Mediterranean Foraminifera, Slovenska Academia Znanosti in Umetnosti, Ljubljania, 119 pp.

Debenay, J.P., Guillou, J.J., Redois, F., Geslin, E. 2000. Distribution trends of foraminiferal assemblages in paralic environments: a base for using foraminifera as bioindicators, In: Martin, R.E. (ed.), Environmental Micropaleontology, Topics in Geobiology 15, New York: Kluwer Acad. \& Plenum Publ., 39-67.

Donnici, S., Serandrei-Barbero, R., 2005. I foraminiferi di ambiente vallivo della Laguna di Venezia, Lavori Societa`Veneziana Scienze Naturali 30, 25-36.

Dornbos, S.Q., Wilson, M.A. 1999. Paleoecology of a Pliocene coral reef in Cyprus: recovery of a marine community from the Messinian salinity crisis, N. Jahrb Geol. Palaeontol Abh, 21, 103-118.

Dürr, St., Jacobschagen, V. 1986. Ostägäische Inseln, In: Jacobshagen, V. (ed.) Geologie von Griechenland, Berlin, Gebrüder Borntraeger, 169-187.

Gralla, P. 1982. Das Präneogen der Insel Kos (Dodekanes, Griechenland), PhD Thesis, University of Braunschweig, 182 pp.

Hayward, B.W Sa;baa, A.T., Grenfell, H.R. 2004. Benthic foraminifera and the Late Quaternary (last 150 ka) paleoceanographic and sedimentary history of the Bounty Trough, east of New Zealand, Palaeogeography Palaeoclimatology Palaeoecology 211(1-2), 59-93.

Henjes-Kunst, F., Altherr, R., Kreuzer, H., Hansen, B.T. 1988. Disturbed U-Th-Pb systematic of young zircons and uranothorites: the case of the Miocene Aegean granitoids (Greece), Chemical Geology 73, 125-145. 
Jacobshagen, V. 1986. Introduction, In: Jacobshagen, V. (ed.) Geologie von Griechenland, Berlin, Gebrüder Borntraeger, 1-9.

Jorissen, F.J. 1987. The distribution of benthic foraminifera in the Adriatic Sea, Marine Micropaleontology $12,21-48$.

Jorissen, F.J. 1988. Benthic foraminifera from the Adriatic Sea: priniciples of phenotypic variation., Utrecht Micropaleontological Bulletins 37, 1-174.

Fiorini, F., Vaiani, S.C. 2001. Benthic foraminifers and transgressive-regressive cycles in the Late Quaternary subsurface sediments of the Po Plain near Ravenna (Northern Italy), Bollettino della Società Paleontologica Italiana, 40, 357-403.

Kalt, A.,Altherr, R., Ludwig, T. 1998. Contact Metamorphism in Pelitic Rocks on the Island of Kos (Greece, Eastern Aegean Sea): a test for the Na-in- cordierite thermometer, Journal of Petrology, 663-668.

Keller, J. 1969. Origin of thyolites by anatectic melting of granitic crustal rocks. The example of rhyolitic pumice from the island of Kos (Aegean Sea), Bulletin Volcanologique 33, 942-956.

Langer, M.R, 1993. Epiphytic foraminifera, Marine Micropaleontology 20, 235-265.

Murray, J.W. 1991. Ecology and palaeoecology of benthic foraminifera. Longman, Harlow, 397pp.

Murray, J.W. 2006. Ecology and applications of Benthic Foraminifera. Cambridge University Press, Cambridge, $426 \mathrm{pp}$

Peirano, A., Morri, C., Mastonuzzi, G., Bianchi, C.N. 1998. The coral Cladocora caespitosa (Anthozoa, Scleractonia) as a bioherm builder in the Mediterranean Sea, Mem. Descr. Carta Geol. It. 52, 59-74.

Peirano, A., Abbate, M., Cerrati, G., Difesca, V., Peroni, C., Rodolfo-Metalpa, R. 2005. Monthly variations in calyx growth, polyp tissue and density banding of the Mediterranean scleractinian Cladocora caespitosa (L.), Coral Reefs 19, 404-409.

Schiller, C. 1993a. Ecology of the symbiotic coral Cladocora caespitosa (L.) (Faviidae, Scleractinia) in the Bay of Piran (Adriatic Sea): I Distribution and biometry. Marine Ecology 14, 205-219.

Seidel, E., Schliestedt, M., Kreuzer, H., Harre, W. 1977. Metamorphic rocks of late Jurassic age as components of the ophiolitic mélange on Gavdos and Crete (Greece), Geologisches Jahrbuch B28, 3-21.

Seidel, E., Kreuzer, H., Harre, W. 1982. A late Oligocene/early Miocene high pressure belt in the external Hellenides, Geologcisches Jahrbuch E23, 165-206.

Sen Gupta, B.K. 1999. Foraminifera in marginal marine environments, In: Sen Gupta B.K. (ed) Modern foraminifera, Kluwer, Dordrecht, 141-159.

Sgarrella, F., Moncharmon-Zei, M. 1993. Benthic foraminifera in the Gulf of Naples (Italy): systematic and autoecology, Boll. Soc. Paleont. Ital. 32, 145-264.

Van der Zwaan, G.J., Jorissen, F.J. 1991. Biofacial patterns in river induced shelf anoxia. Geol. Soc. Spec. Publ. 58, 65-82.

Willmann, R. 1983. Neogen und jungtertiäre Enwicklung der Insel Kos (Agäis, Griechenland), Geologische Rundschau 72, 815-860.

Yassini, I., Jones, B.G. 1995. Foraminiferida and Ostracoda from estuarine and shelf environments on the southeastern coast of Australia, University of Wollongong Press, Wollongong, 484 pp.

Zibrowius, H. 1974. Oculina patagonica, scléractiniaire hermatypique introduit en Méditerranée, Helgoländer Wissenschaftliche Meeresuntersuchungen 26 (2), 153-173

Zibrowius, H. 1980. Les Scléractinaires de la Méditerranée et de l'Atlantique nord-oriental, Mém. Inst. Océanogr. 11, 1-284. 